\author{
KRISTINA Ž. RANĐELOVIĆ ${ }^{1}$ \\ UNIVERSITY OF PRIŠTINA IN KOSOVSKA MITROVICA \\ FACULTY OF PHILOSOPHY \\ DEPARTMENT OF PSYCHOLOGY \\ NIKOLA R. GOLJOVIĆ ${ }^{2}$ \\ UNIVERSITY OF NIŠ, FACULTY OF PHILOSOPHY \\ DEPARTMENT OF PSYCHOLOGY
}

\title{
BREAKUP GRIEF - THE DIFFERENCE BETWEEN INITIATOR AND NON-INITIATOR DEPENDING ON COPING STRATEGIES AND ATTACHMENT
}

ABSTRACT. The aim of this paper is to examine the difference in the intensity of the
breakup distress between the initiator and the non-initiator, as well as
whether this difference is moderated by coping strategies and inner work-
ing models according to the attachment theory. The sample used in the
research is convenient and consists of 387 respondents. The age range is
between $18-40(M=23.90 ; S D=4.22)$. We used the Close Relationship Experi-
ence Questionnaire (Brenan, Clark, \& Shaver, 1995), the Brief COPE
(Carver, 1997) and the Breakup Distress Scale (Field \& al., 2010). The t-test
was performed for the independent samples to test the difference between
the breakup initiators and non-initiators in the variable of grief after a
breakup ( $(365)=4.62 ; \mathrm{p}<.01)$. Within the constructed prediction model, a
total of four predictors showed an independent contribution to the explana-
tion of experienced grief after a breakup: the status of the initiator of the
breakup, coping aimed at solving problems, coping with avoidance and
anxiety. Later, by testing the contribution of the predictor and the variable,
the status of the initiator was obtained as a statistically significant interac-

kristina.randjelovic@pr.ac.rs

nikolagoljovic@gmail.com

This paper was submitted on August $8^{\text {th }}, 2020$ and accepted for publication at the meeting of the Editorial Board held on September $25^{\text {th }}, 2020$. 
tion with anxiety. Respondents who have low anxiety do not experience a high level of distress after a breakup and do not differ from each other depending on whether the initiators of the relationship were them or their partner. Respondents who have high anxiety experience a noticeably higher level of emotional distress after the breakup, but there are also differences in that level depending on who initiated the breakup. If the partner initiated the termination, the level of experienced distress will be significantly higher. It seems that presenting as a stressor can be a trigger of an intense emotional reaction, considering that such people are sensitive to rejection by others.

KEYWORDS: breakup grief; romantic relationships; initiator of break up; coping strategy; attachment.

INTRODUCTION

A romantic relationship can be one of the most important relationships in a person's life, while the termination of a relationship can be a painful and stressful event with numerous consequences both for the mental and physical condition of the person. The intensity of distress after a breakup varies, and there is often a difference in its intensity between the initiator and the non-initiator of the breakup. Although it is believed that it is always easier for the one who leaves the relationship, things are not always so simple. There are numerous factors that can make it easier or harder for a person to cope with a situation. Researchers in the field of romantic relationships strive to understand, predict and build conceptual and theoretical models of distress experienced after relationship breakups. This research aims to provide some insights into the distress experienced after a breakup of a relationship in relation to whether a person is the breakup initiator or non-initiator, mediated by coping strategies and the affective attachment style.

\section{INITIATION OF A BREAKUP AND DISTRESS}

Romantic relationships can be the main source of happiness and satisfaction for most people (Berscheid \& Reis, 1998), while on the other hand, a breakup is considered one of the most difficult events in life and a potential risk factor for developing emotional problems (Monroe, Rohde, Seelei, \& Levinsohn, 1999, Menaghan \& Lieb- 
erman, 1986). Interpersonal rejection is known to be a disturbing experience and results in many negative emotional responses (Koch, 2020). In their essence, people are imbued and motivated by the need to belong, i.e. by a strong desire to form and maintain lasting interpersonal relationships (Baumeister \& Leary 1995). The consequences of being rejected by someone in whom a person is emotionally invested have also been shown in laboratory conditions (e.g. Bourgeois \& Leari, 2001; Bucklei, Vinkel, \& Leari, 2004; Leari, Cottrell, \& Phillips, 2001; Leari, Haupt, Strausser, \& Chokel, 1998, according to Waller, 2010) where people are quite sensitive even to mild forms of interpersonal rejection, such as imagined rejection. Relationship dissolution was one of the most commonly nominated "worst events" in a large phone survey study of traumatic events (Frazier \& Hurliman, 2001). After a breakup, people experience more emotional distress than those who have never been through a breakup (Stack, 1989; Tschann, Johnston \& Vallerstein, 1989, according to Chung \& al., 2003). They tend to experience significantly more negative emotions (e.g., frustration, depression, and loneliness) than positive ones (e.g., love and relief, Sprecher, 1994). Moreover, psychological and physical symptoms lasting longer than 6 months may occur, such as insomnia, depression, suicidal thoughts, especially among young people (Williams \& Siegel, 1989). However, as with other stressful life events, not everyone reacts in the same way (Bonanno, 2004).

Most breakups are not mutual, i.e. there is a difference between the one who "leaves" and the one who is "left" (Hill, Rubin, Zick, \& Peplau, 1976; Sprecher, 1994; Vaughan, 1986; Weiss, 1975, according to Chung \& al., 2003), therefore, the reactions to the dissolution of a romantic relationship may differ depending on who initiated the breakup. Numerous studies show that non-initiators of break-up, regardless of gender, report more emotional and/or physical distress compared to initiators (Davis \& al., 2003; Collins \& Clark, 1989; Frazier \& Cook, 1993; Sprecher, 1994; Sprecher \& al., 1998). Studies suggest that individuals who take responsibility for breaking up a romantic relationship adapt better to a breakup (Collins \& Clark, 1989) than those who have no control over that decision, and therefore respond with greater intensity of sadness and depression (Frazier \& Cook, 1993; Field \& al., 2009; Sprecher \& al., 1998). Regardless of gender, the perception that the partner initiated the breakup is positively correlated with the intensity of the distress (Sprecher \& al., 1994; Attridge \& al. 1995). People who believe 
they have no control over a breakup or future relationships tend to develop more depressive symptoms than those who think otherwise (Peterson, Rosenbaum, \& Conn, 1985). However, there are also findings that did not observe the difference between the initiator and non-initiator of a breakup in terms of emotional distress (Sbarra, 2006; Simpson, 1990; Tashiro and Frazier, 2003). Since these studies do not systematically differ from each other in terms of the types of dependent variables used, the time period elapsed since the breakup, or whether the respondents are from a complete/ incomplete family, these conflicting results are confusing. Moreover, the results suggest that initiator status does not always predict the same intensity of emotional distress after a breakup (Waller \& MacDonald, 2010). Furthermore, the person that rejects is not without emotional consequences either, rejecting other person results in feelings of guilt and the need for justification (Baumeister \& al., 1993). Breakup initiator can experience negative emotions just like the non-initiator, therefore the initiator status cannot in itself consistently predict the intensity of reaction to the termination of a relationship (Waller \& MacDonald, 2010). Waller \& al. (2010) argue that a situation in which a partner initiates a breakup generally causes greater distress than when a person makes that decision on their own, although this difference is small in itself if moderator variables are not considered. Break-up initiator status and self-esteem are significant predictors of emotional distress, self-evaluation, and self-esteem after a romantic breakup among students (Waller \& MacDonald, 2010). Moreover, the intensity of distress may depend on factors such as relationship length, relationship satisfaction, commitment, partner dependence, type of attachment, existence of alternative partners, coping mechanisms, self-esteem (Fine \& Sacher, 1997; Sprecher \& al., 1998; Frazier \& Cook, 1993; Chung \& al., 2003; Koch, 2020).

\section{COPING STRATEGIES}

Coping strategies play an important role in the intensity of distress after a breakup. They are most often defined as the behavioral and cognitive efforts to overcome, reduce or tolerate the demands of a stressful situation (Lazarus \& Folkman, 1984). Coping is a mediator of stress, i.e., it implies that stress and various disorders are not directly related, but rather that stress is a factor that triggers cop- 
ing behavior, which is actually related to the outcomes of stress (Zotović, 2004). Choosing an appropriate coping behavior depends on stressor characteristics, but also on internal and external factors of individual differences, i.e. moderator variables. Coping has two functions - to solve the problem and regulate emotions. Coping strategies can take many forms, such as active problem solving, information seeking, diverting attention from problems, reducing tension, using humor (Kessler \& al., 1985). Krohne (according to Zotović, 2004), distinguishes two basic modes of coping strategies in relation to the focus of attention: directing attention, which involves coping styles that include intensive search for information related to the stressful event and their processing; and cognitive avoidance, which involves distraction from any stimuli and information related to the stressful event. Other authors call the same dimension goal-directed or active coping versus avoidant or passive coping (Ebata \& Moos, 1991; Roth \& Cohen, 1986, according to Zotović, 2004). Lagrand (1988, according to Chung, 2003) describes some of the coping strategies such as talking to friends, seeking advice, seeking support from people who have gone through a similar experience, thinking about opportunities and choices, focusing on work, forming new relationships, focusing on religion, expressing negative emotions such as anger and sadness. Seeking and receiving social support is one of the most important strategies. It implies that a person feels safe because he or she has people to rely on and who are available to listen and provide support (Chung, \& al.,2003). The increase in psychological issues due to a negative life event is most often associated with a lack of social support (Kessler $\&$ al., 1985). Some people look for ways to develop a sense of control over the situation and reduce negative emotional consequences after the breakup. Planning or coming up with a problem-solving strategy reduces the intensity of distress, while using strategies that distance a person from problem-solving, such as avoidance, is associated with negative emotional consequences after a traumatic event (Mearns, 1991).

\section{ATTACHMENT STYLE}

Attachment style plays an important role in successfully overcoming the dissolution of a romantic relationship (Madey \& Jilek, 2012). Sroufe and Waters (1977) believe that attachment theory should be 
viewed as a theory of regulation, that is, that different attachment styles may have different mechanisms for regulating and mitigating the negative impact of problems in a romantic relationship. Theoretically speaking, attachment system is activated due to distress and the person reacts in a way specific to their attachment style, in order to reduce the intensity of distress (Davis \& al., 2003). The stronger the activation of the attachment system, the more extreme the characteristic behaviors are likely to be. Davis \& al (2003) mention three main post-breakup distress coping strategies that are related to affective attachment style. People with prevalent the secure attachment style cope better with negative events in relationships and are more skilled in looking at a negative situation from a positive angle than people with prevalent avoidant or anxious attachment style. They tend to build positive and well-adjusted relationships, and other people describe them as confident and less hostile people. These individuals are characterized by a positive model of themselves and a positive model of others (Bowlby, 1973), as well as greater self-confidence, self-esteem, and a lower degree of anxiety compared to those who are insecurely attached (Feeney \& Noller, 1990).

Secure attachment is associated with less concern about seeing an ex-partner again post-breakup, a greater willingness to reunite, and a lower sense of guilt compared to insecure attachment (Madey \& Jilek, 2012). Secure attachment strategy is characterized by open, empathetic communication, negotiation about someone's needs and desires. These people openly express their feelings to their partner and rely on family and friends when they need support. They also have greater understanding of the reasons for a breakup, which allows them to react less aggressively and histrionically unlike the insecure types (avoidant, anxious). Insecure attachment type - avoidant and anxious type, experience more distress post-breakup and report that their breakup was hostile and that the partner is more to blame for the breakup. Insecure attachment types tend to use inadequate coping strategies such as distancing, wishful thinking and self-defeating thoughts (Birnbaum, Orr, Mikulincer, \& Florian, 1997; Mikulincer, Florian, \& Veller, 1993; Sprecher, Felmlee, Metts, Fehr and Vanni, 1998, according to Madey \& Jilek, 2012). People with avoidant attachment style use strategies aimed at reducing negative consequences of distress post-dissolution by relying only on themselves. These people have learned that other people cannot respond adequately to their 
needs and that open expression of needs could be ignored or punished in some way (Fraley \& al., 1998). After a breakup, such people will have less emotional outbursts such as anger, begging, seeking social support, but will turn to emotional avoidance by using alcohol and psychoactive substances, avoiding partners and situations/ objects that may be associated with the former relationship and activate the need for connection. Highly avoidant individuals report significantly less emotional distress following romantic break-ups compared to other attachment types (Simpson, 1990). On the other hand, an important characteristic of the anxious type is similar to "desperate love" style that Sperling (1985) describes in his research, and refers to the idealization of the partner, feelings of insecurity outside the relationship, separation anxiety, and extremes of happiness and sadness. Anxious type strategy includes alternation of anger and submission or flirting in an attempt to renew a relationship. People with an anxious or preoccupied attachment style have learned to "meet their needs" with the "coercive strategy" (Crittenden, 1992). Each strategy stems from experiences with parents or guardians during childhood, as well as later experiences with romantic partners (Stefanović Stanojević, 2011). Individual differences in behavior based on attachment style are the consequences of expectations and beliefs that a person has about him/herself and about his/her close relationships, and also based on affective relationships in the past. Although different studies highlight negative effects of a breakup, a relationship does not necessarily have to end with animosity. Unlike insecure attachment, secure attachment is associated with successful dissolution of a relationship. Partners can have an amicable breakup, which results in mutual respect and a willingness to remain friends (Madey \& Jilek, 2012).

The focus of this paper is a more detailed examination of whether there is a difference in the intensity of emotional distress after a breakup in the breakup initiator and non-initiator. As previous studies are inconsistent in regard to results, the aim of this paper is to examine the conditions under which such a change in results occurs, i.e. whether this relationship is moderated by some other variables, which might cause the results to be inconsistent. Theory speaks in favor of the existence of a difference, as well as certain empirical results, but it is obvious that some characteristics concerning the respondents play an important role here. The first such characteristic is related to emotional personality development, 
assuming that early development and early experiences will create the capacity to make it easier or more difficult to overcome the loss of an attachment figure. On the other hand, there are behavior patterns in situations that we perceive as stressful, that is, stress coping strategies. We assumed that less developed capacity to cope with stressful situations could be significant in understanding potential differences. In accordance with research objectives, the following hypotheses were defined:

h1: It is assumed that there is a difference between the initiator and non-initiator of a relationship breakup in the emotional distress they experience after the breakup.

h2: This difference in the emotional distress that exists between the initiator and non-initiator of a relationship breakup is moderated by coping strategies and attachment style.

\section{SAMPLE}

The sample used in this research is a convenience sample and consists of 387 respondents, $82,7 \%$ of which are females. The age range is between 18-40 ( $\mathrm{AS}=23.90 ; \mathrm{SD}=4.22)$. All respondents stated that they have had at least one romantic relationship breakup so far $(\mathrm{Mod}=3)$. Of the total number of respondents, $60.7 \%$ are currently in a romantic relationship. The majority of respondents lives in urban (68\%) and suburban areas (19.4), while a smaller number of them live in rural areas (12.7\%). An important variable in this study relates to whether respondents initiated a breakup more often and it was their partners who were breakup initiators more frequently. A total of $71.8 \%$ of respondents fall under the category of respondents who more often initiated the breakup of a relationship, i.e. 278 respondents, whereas 109 respondents fall into the other category i.e. their partner initiated the breakup.

\section{INSTRUMENTS}

Close Relationship Experience Questionnaire (PAVa; Brennan, Clark \& Shaver, 1998). The questionnaire consists of 18 items related to experiences in love relationships. This questionnaire exam- 
ines how a person feels in any relationship with a loving partner (girlfriend, boyfriend, husband, wife) rather than how specific they feel in the relationship, if any. The sum of scores on the even items refers to the Anxiety dimension, which when it comes to partnerships can be briefly described by behaviors such as: worrying about reciprocating love, worrying about possible leaving, needing too much closeness. On the other hand, the sum of points on odd items refers to the Avoidance dimension, which represents the ability, that is, the inability to establish closeness with others. The answers are given on a seven-point Likert-type scale (1 - strongly disagree; 7 - strongly agree). Higher scores on the Anxiety and Avoidant subscales indicate higher levels of attachment anxiety and attachment avoidance, respectively. The reliability in the initial version of the instrument was higher than .90 on both scales, which indicates the high reliability of the instrument.

Brief COPE (Carver, 1997; translated and adapted for Serbian language by Šakotić-Kurbalija, J. and Kurbalija, D.) is the scale that operationalizes mechanisms to cope with stress. It is a 28 -item questionnaire with a five-point Likert type scale. In the initial sample, the scale showed acceptable reliability (.71). Previous checks of the factor structure of the scale have not yielded consistent results, with some meta-analyzes of these studies indicating that the number of extracted factors in different studies varied between 2 and 12 (Krägeloh, 2011; Parker \& Endler, 1992). In this study, we used the factor structure extracted in the validation study in one domestic study (Genc, Pekić and Matanović, 2013), whose factor structure most closely resembled the one obtained in this study. Based on the matrix of the structure and structure of isolated factors, it was found that most items are grouped quite meaningfully around three factors that are named as: Seeking social support („I had emotional support from others.“, „I tried to seek advice or help from other people“, „I received comfort and understanding from someone“), Problem-oriented coping (,I focused all my efforts on doing something about the situation I found myself in", „I tried to plan what needs to be done“, „I took some action to improve the situation") and Coping with avoidance (,I told myself: this is not happening to me", „I drank alcohol or medication to feel better.", "I gave up trying to deal with it.").

Breakup Distress Scale (Breakup Distress Scale, Field \& al., 2010) was created by adapting the Inventory of Complicated Grief, which examines the distress after the death of someone close. This ques- 
tionnaire examines distress after relationship dissolution and consists of 16 items (while the original questionnaire had 19) that are related to breakup (e.g. I think about this person so much that it's hard for me to do things I normally do). Items on this scale measure indicators such as: preoccupation with thoughts of the breakup, crying, not accepting the breakup and being stunned by the breakup. Translation and adaptation of this scale was done for the purposes of this research using the back translation method. Participants completed the tests by replying to statements on a scale of 1 (strongly disagree) to 5 (strongly agree). The overall result is the sum of the values obtained on individual items. The possible range of results goes from 16 to 80 with a higher score indicating more distress after a breakup. Items measure a range of reactions such as feeling bitter and empty since the breakup. Examples of the items include "I feel disbelief over what happened," and "I feel lonely a great deal of the time since the breakup." The EFA results confirmed that it is possible to interpret one total factor indicating the distress experienced. The reliability of the scale in the initial version of the test is high.

\section{DATA COLLECTION PROCESS}

Data were collected through computer-aided testing. Respondents first confirmed that they were familiar with their rights and testing rules, and then moved on to the questions section. Moreover, they were given the opportunity to leave at any time, so the answers would be saved only when the respondent entered all the necessary data and sent them to the database, and in case of leaving, no traces of the respondent's participation were recorded.

\section{RESULTS}

\begin{tabular}{|l|r|r|r|r|r|r|r|r|r|r|r||}
\hline Indicator & 1 & 2 & 3 & 4 & 5 & Min & Max & M(SD) & Sk & Ku & $\alpha$ \\
\hline $\begin{array}{l}\text { 1. Break-up } \\
\text { distress }\end{array}$ & - & & & & & 1 & 5 & $2.51(1.02)$ & .42 & -.90 & .94 \\
\hline 2. Anxiety & $.46^{* *}$ & & & & & 1 & 4.89 & $2.48(.87)$ & .40 & -.42 & .86 \\
\hline
\end{tabular}

TABLE 1: PRESENTS DESCRIPTIVELY THE STATISTICAL MEASURES OF THE VARIABLES USED IN THE SURVEY 
BREAKUP GRIEF - THE DIFFERENCE BETWEEN INITIATOR AND NON-INITIATOR

\begin{tabular}{|l|r|r|r|r|r|r|r|r|r|r|r|}
\hline 3. Avoidance & -.02 & .05 & & & & 1 & 4,56 & $1.9(.77)$ & .95 & .25 & .81 \\
\hline 4. Problem & $-.17^{* *}$ & $-.12^{*}$ & $-.17^{* *}$ & & & 1.36 & 5 & $3.93(.66)$ & -.70 & .51 & .71 \\
\hline 5. Support & .07 & $.17^{* *}$ & $-.16^{* *}$ & $.33^{* *}$ & & 1 & 5 & $3.47(.72)$ & -.36 & .26 & .71 \\
\hline 6. Avoidance & $.31^{* *}$ & $.37^{* *}$ & $.14^{* *}$ & $-.14^{* *}$ & $.41^{* *}$ & 1 & 5 & $2.49(.60)$ & .48 & .33 & .68 \\
\hline
\end{tabular}

TABLE 1: PRESENTS DESCRIPTIVELY THE STATISTICAL MEASURES OF THE VARIABLES USED IN THE SURVEY

${ }^{*} p<.05,{ }^{* *} p<.01$

The results indicate that there is a statistically significant correlation between predictors and criteria, as well as that the level of correlation between predictors is not too high (it is of a medium level), so there is no fear that multicollinearity might occur. Measures of Skewness and Kurtosis indicate that there is no excessive deviation from normal distribution for all variables, so the authors were therefore inclined to use parametric methods. Cronbach's alpha, as a measure of internal consistency, indicates that the reliability of all scales is satisfactory, ranging from low to high. The t-test was performed for the independent samples to test the difference between the breakup initiators and non-initiators in the variable of grief after a breakup. The results have confirmed the hypothesis that claimed the differences existed $(t(365)=4.62 ; p<.01)$. The obtained difference indicates that respondents whose partners were more often initiators of a breakup experienced a higher level of grief post-breakup $(\mathrm{M}=2.88 ; \mathrm{SD}=1.05)$, than respondents who initiated breakups more often $(\mathrm{M}=2.36 ; \mathrm{SD}=.98)$.

In order to predict the distress experienced after the breakup, a regression model was constructed in which the dimensions of coping with stress, attachment style and the categorical variable of breakup initiator-non-initiator were entered as predictors. The regression function obtained significantly explains the examined criterion. Its form is: $R^{2}=.28 ; F(6,380)=24.38, p<.001$. Properties of predictors in the regression model are given in the following table:

\begin{tabular}{|c|l|l|l|l|l|}
\hline & B & SE & $\beta$ & $t$ & $r 0$ \\
\hline INITIATOR & -.36 & .10 & -.16 & $-3.53^{* *}$ & -.23 \\
\hline PROBLEM & -.18 & .08 & -.11 & $-2.26^{*}$ & -.16 \\
\hline
\end{tabular}

TABLE 2: REGRESSION COEFFICIENTS IN PREDICTION OF BREAKUP GRIEF BASED ON ATTACHMENT, COPING AND BREAKUP INITIATOR STATUS 


\begin{tabular}{|c|l|l|l|l|l|}
\hline SUPPORT & -.06 & .08 & -.04 & -.78 & .07 \\
\hline AVOIDANCE & .30 & .09 & .17 & $3.24^{* *}$ & .31 \\
\hline ANXIETY & .43 & .06 & .37 & $7.64^{* *}$ & .46 \\
\hline AVOIDANCE & -.11 & .06 & -.08 & -1.79 & -.02 \\
\hline \hline
\end{tabular}

TABLE 2: REGRESSION COEFFICIENTS IN PREDICTION OF BREAKUP GRIEF BASED ON ATTACHMENT, COPING AND BREAKUP INITIATOR STATUS

Note: $B$ - unstandardized regression coefficient; $S E$ - standard error; $\beta$ standardized regression coefficient; $t-t$ value; ${ }^{*} p<.05,{ }^{* *} p<.01 ; r 0-$ zero-order correlation between predictors and criteria

As we can see from the table, a total of four predictors show an independent contribution to explaining the criteria: breakup initiator status $(\beta=-.16, p<.01)$, problem-focused coping $(\beta=-.11, p<$ $.05)$, and avoidance coping $(\beta=.17, p<.01)$ but the greatest contribution to explaining distress after a breakup is provided by high attachment anxiety $(\beta=.37, \beta<.01)$.

After the initial regression model was obtained, the contribution of each of the double interactions between stress coping variables and working models with initiator status during the breakup was tested. The following table only shows interactions that are statistically significant.

As we can see, the multivariance of the predictor of post-breakup grief variable is not too abundant in interactions, i.e. only one statistically significant interaction was obtained for the Anxiety dimension, while a marginally statistically significant interaction was obtained for the Problem dimension, which will only be mentioned this time.

Understanding the interactions between variables greatly facilitates their visual presentation, and the method we used is based on choosing two states (high and low) and their combination which results in four potential solutions (Aiken \& West, 1991). High and low scores are defined as one standard deviation above and below the mean value (Chaplin, 2007).

As we can see in the graph, respondents who had low level of attachment anxiety, i.e. positive working model of the self, do not experience a high level of distress after the breakup and do not differ from each other depending on whether they were the breakup initiators or it was their partner. On the other hand, when it comes to respondents who have high level of attachment anxiety, i.e. negative working model of the self, the situation is different. Firstly, 


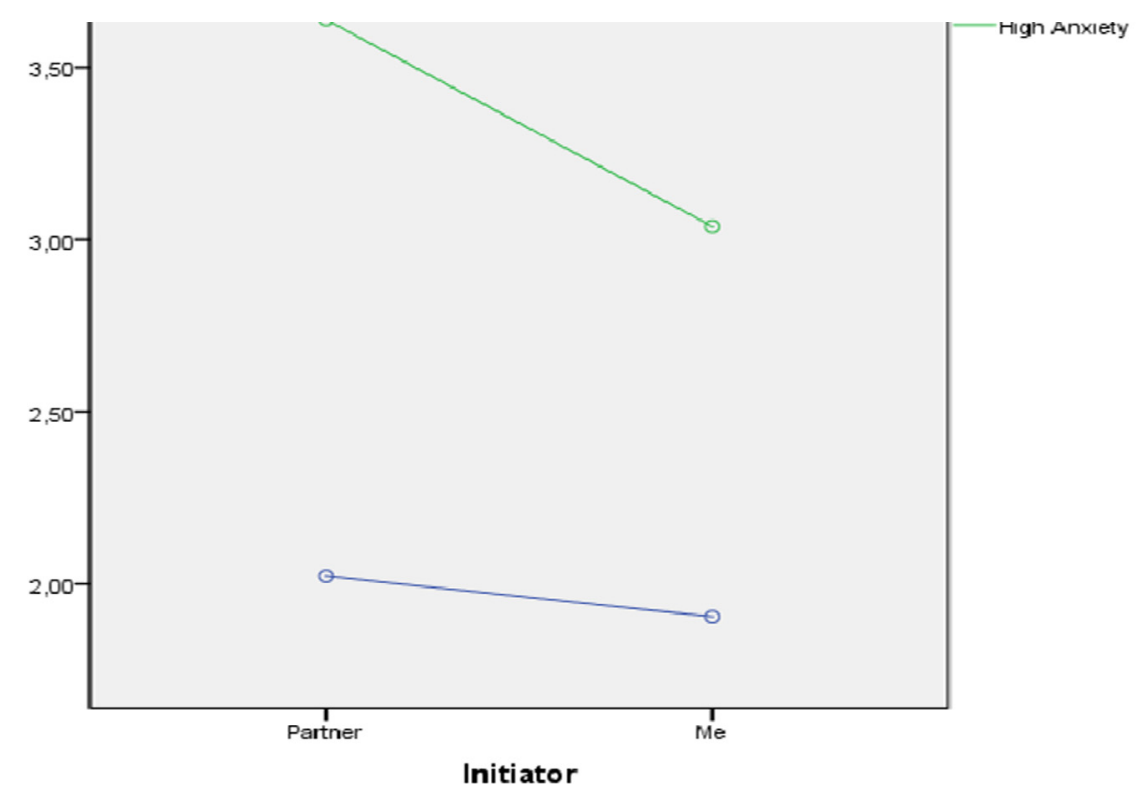

they differ significantly from respondents with low attachment anxiety scores, because they experience a significantly higher level of emotional distress after a breakup, however, that level of distress also depends on who the breakup initiator is. If the partner initiated the breakup, the level of distress will be significantly higher.

\section{DISCUSSION AND CONCLUSION}

This research aimed to provide a more detailed insight into whether there is a difference in the intensity of distress after a romantic relationship breakup in the person who initiated the breakup and in the person who did not initiate it, and what that difference depends on. The initial research hypotheses were that there is a difference in the intensity of distress between the breakup initiator and non-initiator, and that this difference is moderated by coping strategies and attachment style.

It is well-known that the termination of a romantic relationship is considered one of the most difficult events in life and a potential risk factor for developing emotional problems (Monroe, Rohde, Seelei, \& Levinsohn, 1999, Menaghan \& Lieberman, 1986). In their essence, people are imbued and motivated by the need to belong, i.e. by a strong desire to form and maintain lasting interpersonal 
relationships (Baumeister \& Leary 1995), therefore, interpersonal rejection is known to be a disturbing experience and results in many negative emotional responses (Koch, 2020). Numerous studies show that non-initiators of break-up, regardless of gender, report more emotional and/or physical distress compared to initiators (Davis \& al., 2003; Collins \& Clark, 1989; Frazier \& Cook, 1993; Sprecher, 1994; Sprecher \& al., 1998). Studies suggest that individuals who take responsibility for breaking up a romantic relationship adapt better to a breakup (Collins, 1989) than those who have no control over that decision, and therefore respond with greater intensity of sadness and depression (Frazier \& Cook, 1993; Field \& al., 2009; Sprecher \& al., 1998). On the other hand, there are also findings that did not observe the difference between the initiator and non-initiator of a breakup in terms of emotional distress (Sbarra, 2006; Simpson, 1990; Tashiro and Frazier, 2003). Breakup initiator can experience negative emotions just like the non-initiator, therefore the initiator status cannot in itself consistently predict the intensity of reaction to the termination of a relationship (Waller \& MacDonald, 2010).

The first specific goal of this study relates to the need to examine whether there is a statistically significant difference in the given sample between respondents who are break-up initiators and those who are not. The hypothesis that there is a difference has been confirmed, and the results indicate that people who were more often non-initiators of a breakup experience a higher level of stress when a relationship dissolves.

Although both groups report a high level of distress after a breakup, the score is higher for non-initiators. The person that rejects is not without emotional consequences either, rejecting other person results in feelings of guilt and the need for justification (Baumeister \& al., 1993), which can explain the result obtained in this study. Another specific objective relates to examining the conditions under which such a difference exists. The above-mentioned inconsistent results (Sbarra, 2006; Simpson, 1990; Tashiro and Frazier, 2003) point to the existence of potential mediators, and the moderation effect of coping mechanisms and attachment dimensions was examined in this paper. Previous studies suggest that self-esteem can be a significant predictor of emotional distress after a breakup (Waller \& MacDonald, 2010), as well as relationship length, relationship satisfaction, commitment, partner dependence, attachment type, existence of alternative partners, coping 
mechanisms, self-esteem (Fine \& Sacher, 1997; Sprecher \& al., 1998; Frazier \& Cook, 1993; Chung \& al., 2003; Koch, 2020).

In regard to coping strategies, they have not been proven to be statistically significant moderators that can help to better understand the difference in the intensity of distress between the initiator and non-initiator of a romantic relationship breakup. A marginally statistically significant interaction was obtained for the problem-focused coping dimension and the authors decided to present this in order to highlight the potentially significant role of coping strategies for further research, especially the ability to overcome stress caused by emotional states and losses.

Attachment style, i.e. high level of attachment anxiety, proved to be able to best explain the post-breakup distress in this research. Previous studies support the claim that attachment style plays an important role in successfully overcoming the dissolution of a romantic relationship (Madey \& Jilek, 2012). Attachment system is activated due to distress and the person reacts in a way specific to their attachment style, in order to reduce the intensity of distress (Davis \& al., 2003). Three sources of distress can activate the attachment system: a threat to a person such as hunger or physical danger; threat to the bond with the attachment figure, that is, perceiving the figure as physically or psychologically inaccessible; challenging situations that motivate a person to use the attachment figure as a base of security. When the system is activated for any of the above reasons, the person tries to alleviate the intensity of emotional reaction in ways that characterize his or her attachment style. The stronger the activation of the attachment system, that is, the higher the distress for a person, the more extreme the characteristic behaviors are likely to be.

A better understanding of the difference in distress depending on the attachment style is provided by the working model of the self and others. Early attachment-related experiences and working models created in childhood have long-term consequences on shaping an individual's future expectations and the quality of his or her close relationships in adulthood (Bowlby, 1973). In this study, respondents who had low level of attachment anxiety, i.e. positive working model of the self, do not experience a high level of distress after the breakup and do not differ from each other depending on whether they were the breakup initiators or it was their partner. They see themselves as worthy of someone else's care and love, they cope well with negative events in relationships and are skilled 
in looking at a negative situation from a positive angle (Simpson, 1990). These people also have greater understanding of the reasons for a breakup, which allows them to react calmly and composedly. On the other hand, when it comes to respondents who have high level of attachment anxiety, i.e. negative working model of the self, the results are quite different. First of all, they differ significantly from respondents with low attachment anxiety scores, because they experience a significantly higher level of emotional distress after a breakup. If the partner initiated the breakup, the level of distress will be significantly higher. Anxiety is positively correlated with more intense immediate negative reactions and a higher level of rumination in regard to reacting to negative events (Gentzler \& al., 2010). Highly anxious people tend to experience more intense feelings and more variable "highs and lows" in their relationships than other people (e.g. Collins \& Read, 1990; Hazan \& Shaver, 1987). In general, individuals with high anxiety scores are highly reactive (Brennan and Bosson 1998; Carnellei \& al. 2007; Collins and Feeney 2004), which explains significantly higher level of emotional distress after a breakup obtained in this study. Furthermore, people with high anxiety score are characterized by fear of abandonment, they crave emotional support, intimacy, and seek confirmation of their worth from their romantic partners (Hazan and Shaver, 1987). They see themselves as unworthy of love, tend to idealize their partner and have a sense of insecurity outside the relationship (Sperling, 1985). Moreover, anxious people report greater anxiety and impulsivity in their social interactions (Shaver \& Brennan, 1992) and experience stronger negative emotions in their romantic relationships (Simpson, 1990). As a stressful event, breakup is a trigger for people with high anxiety, to which they react with high intensity of distress, and the context itself further intensifies the negative affect, given that anxious people are very sensitive to rejection by others. This type of experience, that is, rejection, activates the attachment system - a negative model of self that a person has, which increases the intensity of emotional response.

This research found that a better understanding of the differences in distress depending on attachment style is provided by the working model of the self and the working model of others, i.e. the context of individual differences within the attachment theory. It is clear that variables related to individual differences are important for a better understanding of this relationship, and therefore, the inclusion of other variables related to personality and self-worth 
could provide significant insight. It is well-known that the stability of emotional reactions can be influenced by personality traits such as neuroticism (Smith \& al., 1989; Watson \& Clark, 1984; McCrae \& Costa, 1990). In addition to this, it is necessary to keep in mind the limitations of this paper regarding the type of distress experienced. The research did not control which relationship type the respondents had in mind when answering the questions. The responses were viewed as a self-assessment of the general response in a particular breakup situation. Grief after a breakup is very likely to be caused by the level of attachment to a particular partner. The length of the relationship which ended with a breakup also needs to be a controlled variable.

Regardless of certain methodological limitations of this paper, its advantages are reflected in a more detailed insight into the important issue of overcoming emotional difficulties associated with relationship breakups as very intense and emotional experiences, which are very common in everyday life and in psychologists' practice. Therefore, it is necessary to dedicate more attention to the study of the relationship dissolution process and ways of overcoming it, almost as much as of the consequences on the mental health and mental life of the partner that more or less painful breakup experiences can cause.

LITERATURE Aiken, L. S., West, S. G., \& Reno, R. R. (1991). Multiple regression: Testing and interpreting interactions. Newbury Park, CA: Sage.

Attridge, M., Berscheid, E., \& Simpson, J. (1995). Predicting relationship stability from both partners versus one. Journal of Personality and Social Psychology, 69(2), 254.

Baumeister, R. F., \& Leary, M. R. (1995). The need to belong: desire for interpersonal attachments as a fundamental human motivation. Psychological bulletin, 117(3), 497.

Baumeister, R. F., Wotman, S. R., \& Stillwell, A. M. (1993). Unrequited love: On heartbreak, anger, guilt, spiritlessness, and humiliation. Journal of Personality and Social Psychology, 64(3), 377.

Berscheid, E., \& Reis, H. T. (1998). Attraction and close relationships. In D. T. Gilbert, S. T. Fiske, \& G. Lindzey (Eds.), The handbook of social psychology (p. 193-281). McGraw-Hill.

Bonanno, G. A. (2004). Loss, trauma, and human resilience: Have we underestimated the human capacity to thrive after extremely aversive events?. American psychologist, 59(1), 20. 
Bowlby, J. (1973), Attachment and Loss: Vol 2: Separation. New York: Basic Book.

Brennan, K. A., \& Bosson, J. K. (1998). Attachment-style differences in attitudes toward and reactions to feedback from romantic partners: An exploration of the relational bases of self-esteem. Personality and Social Psychology Bulletin, 24(7), 699-714.

Brennan, K. A., Clark, C. L., \& Shaver, P. R. (1998). Self-report measurement of adult attachment: An integrative overview. In J. A. Simpson \& W. S. Rholes (Eds.), Attachment theory and close relationships (pp. 46-76). New York: Guilford Press.

Carnelley, K. B., Israel, S., \& Brennan, K. A. (2007). The role of attachment in influencing reactions to manipulated feedback from romantic partners. European Journal of Social Psychology, 37(5), 968-986.

Chaplin, W. F. (2007). Moderator and mediator models in personality research: A basic introduction. In R. W. Robins, R. C. Fraley, \& R. F. Krueger (Eds.), Handbook of research methods in personality psychology (pp. 602-632). New York: Guilford.

Chung, M. C., Farmer, S., Grant, K., Newton, R., Payne, S., Perry, M, Saunders, J., Smith, C., and Stone, N., (2003). Coping with post?traumatic stress symptoms following relationship dissolution. Stress and Health:Journal of the International Society for the Investigation of Stress, 19(1), 27-36.

Collins, J. E., \& Clark, L. F. (1989). Responsibility and rumination: The trouble with understanding the dissolution of a relationship. Social Cognition, $7(2), 152-173$.

Collins, N. L., \& Feeney, B. C. (2004). Working models of attachment shape perceptions of social support: Evidence from experimental and observational studies. Journal of Personality and Social Psychology, 87, 363-383.

Crittenden, P. M. (1992). Crittenden, PM (1992). Treatment of anxious attachment in infancy and early childhood. Development and Psychopathology. Development and Psychopathology, 4, 575-602.

Davis, D., Shaver, P. R., \& Vernon, M. L. (2003). Physical, emotional, and behavioral reactions to breaking up: The roles of gender, age, emotional involvement, and attachment style. Personality and Social Psychology Bulletin, 29(7), 871-884.

Feeney, J. A., \& Noller, P. (1990). Attachment style as a predictor of adult romantic relationships. Journal of personality and Social Psychology, 58(2), 281.

Field, T., Diego, M., Pelaez, M., Deeds, O., \& Delgado, J. (2009). Breakup distress in university students. Adolescence, 44(176), 705.

Fine, M. A., \& Sacher, J. A. (1997). Predictors of distress following relationship termination among dating couples. Journal of Social and Clinical Psychology, 16(4), 381-388. 
Fraley, R. C., Davis, K. E., \& Shaver, P. R. (1998). Dismissing-avoidance and the defensive organization of emotion, cognition, and behavior. In J. A. Simpson \& W. S. Rholes (Eds.), Attachment theory and close relationships (p. 249-279). The Guilford Press.

Frazier, P. A., \& Cook, S. W. (1993). Correlates of distress following heterosexual relationship dissolution. Journal of Social and Personal Relationships, 10(1), 55-67.

Frazier, P. A., \& Hurliman, L. (2001). Post-traumatic stress disorder following low and high magnitude events. Unpublished manuscript, University of Minnesota, Minneapolis, USA.

Gentzler, A. L., Kerns, K. A., \& Keener, E. (2010). Emotional reactions and regulatory responses to negative and positive events: Associations with attachment and gender. Motivation and emotion, 34(1), 78-92.

Hazan, C., \& Shaver, P. (1987). Romantic love conceptualized as an attachment process. Journal of personality and social psychology, 52(3), 511.

Kessler, R., Price, R., \& Wortman, C. (1985). Social factors in psychopathology: Stress, social support and coping processes. Annual Review of Psychology, 36, 531-572.

Koch, E. J. (2020). Remembering that "Everybody Hurts": The Role of Self-Compassion in Responses to Rejection. Basic and Applied Social Psychology, 42(3), 167-175.

Lazarus, R. S., \& Folkman, S. (1984). Stress, appraisal, and coping. New York: Springer Publishing Company.

Madey, S. F., \& Jilek, L. (2012). Attachment style and dissolution of romantic relationships: Breaking up is hard to do, or is it?. Individual Differences Research, 10(4).

McCrae, R.R., \& Costa, P.T., Jr. (1990). Personality in adulthood. New York, Guilford.

Mearns, J. (1991). Coping with a breakup: Negative mood regulation expectancies and depression following the end of a romantic relationship. Journal of Personality and Social Psychology, 60(2), 327.

Menaghan, E. G., \& Lieberman, M. A. (1986). Changes in depression following divorce: A panel study. Journal of Marriage and the Family, 319-328.

Monroe, S. M., Rohde, P., Seeley, J. R., \& Lewinsohn, P. M. (1999). Life events and depression in adolescence: Relationship loss as a prospective risk factor for first onset of major depressive disorder. Journal of abnormal psychology, 108(4), 606.

Peterson, C., Rosenbaum, A. C., \& Conn, M. K. (1985). Depressive mood reactions to breaking up: Testing the learned helplessness model of depression. Journal of Social and Clinical Psychology, 3(2), 161-169. 
Sbarra, D. A. (2006). Predicting the onset of emotional recovery following nonmarital relationship dissolution: Survival analyses of sadness and anger. Personality and Social Psychology Bulletin, 32(3), 298-312.

Shaver, P. R., \& Brennan, K. A. (1992). Attachment styles and the "Big Five" personality traits: Their connections with each other and with romantic relationship outcomes. Personality and Social Psychology Bulletin, 18(5), 536-545.

Simpson, J. A. (1990). Influence of attachment styles on romantic relationships. Journal of personality and social psychology, 59(5), 971.

Smith, T.W., Pope, M.K., Rhodewalt, F., \& Poulton, J.L. (1989). Optimism, Neuroticism, coping and symptom reports: An alternative interpretation of Life Orientation Test. Journal of Personality and Social Psychology, 56, 640-648.

Sperling, M. B., \& Berman, W. H. (1991). An attachment classification of desperate love. Journal of Personality Assessment, 56(1), 45-55.

Sprecher, S. (1994). Two sides to the breakup of dating relationships. Personal relationships, 1(3), 199-222.

Sprecher, S., Felmlee, D., Metts, S., Fehr, B., \& Vanni, D. (1998). Factors associated with distress following the breakup of a close relationship.Journal of Social and Personal Relationships, 15(6), 791-809.

Sroufe, L. A., \& Waters, E. (1977). Attachment as an organizational construct. Child development, 1184-1199.

Stanojević, T. (2011). Afektivna vezanost: razvoj, modaliteti i procena. Niš: Filozofski fakultet.

Tashiro, T. Y., \& Frazier, P. (2003). "I'll never be in a relationship like that again": Personal growth following romantic relationship breakups. Personal Relationships, 10(1), 113-128.

Waller, K. L., \& MacDonald, T. K. (2010). Trait Self?Esteem Moderates the Effect of Initiator Status on Emotional and Cognitive Responses to Romantic Relationship Dissolution. Journal of personality, 78(4), 1271-1299.

Watson, D., \& Clark, L.A. (1984). Negative Affectivity: The disposition to experience aversive emotional states. Psychological Bulletin, 96, 465-490.

Williams, J., \& Siegel, J. P. (1989). Marital disruption and physical illness: The impact of divorce and spouse death on illness. Journal of Traumatic Stress, 2(4), 555-562.

Zotović, M. (2004). Prevladavanje stresa: konceptualna i teorijska pitanja sa stanovišta transakcionističke teorije. Psihologija, 37(1), 5-32. 
КРИСТИНА Ж. РАНЪЕЛОВИЋ

УНИВЕРЗИТЕТ У ПРИШТИНИ СА ПРИВРЕМЕНИМ СЕДИШТЕМ

У КОСОВСКОЈ МИТРОВИЦИ, ФИЛОЗОФСКИ ФАКУЛТЕТ

КАТЕДРА ЗА ПСИХОЛОГИЈУ

НИКОЛА Р. ГОљОВИЋ

УНИВЕРЗИТЕТ У НИШУ

ФИЛОЗОФСКИ ФАКУЛТЕТ

ДЕПАРТМАН ЗА ПСИХОЛОГИЈУ

САЖЕТАК

$$
\begin{gathered}
\text { ТУГОВАҢЕ НАКОН РАСКИДА - РАЗЛИКА ИЗМЕЂУ } \\
\text { ИНИЦИЈАТОРА И НЕИНИЦИЈАТОРА У ЗАВИСНОСТИ } \\
\text { ОД СТРАТЕГИЈА ПРЕВЛАДАВАҢА И АФЕКТИВНЕ ВЕЗАНОСТИ }
\end{gathered}
$$

Партнерски однос може бити један од значајнијих односа у животу једне особе, док раскид романтичне везе може бити болан и стресан догађај са бројним последицама како по психичко тако и по физичко стање особе. Већина раскида није узајамна, односно разликују се онај који „оставља“ и онај који је „остављен“, стога се и реакције на раскид романтичне везе могу разликовати у зависности од тога ко је иницирао раскид. Циљ овог рада је испитати да ли постоји разлика између иницијатора и неиницијатора раскида партнерске везе у нивоу доживљених емоционалних тешкоћа након раскида. Како су претходна истраживања неусаглашена када су резултати у питању, циљ овог рада је испитати под којим условима долази до такве промене у резултатима, тј. да ли је овај однос модериран неким другим варијаблама, због чега су резултати неконзистентни. У фокусу овог рада јесу унутрашњи радни модели теорије афективне везаности и стратегије превладавања стреса. Узорак коришћен у истраживању је пригодан и сачињава га 387 испитаника. Распон година старости је између 18 и 40 (AS=23.90; SD=4.22). Користили смо Close Relationship Experience Questionnaire (Brenan, Clark, Shaver, 1995), Brief COPE (Carver, 1997) и Breakup Distress Scale (Field \& al., 2010). Резултат т-теста је потврдио да иницијатори доживљавају мање проблема са превладавањем раскида од неиницијатора раскида везе $(\mathrm{t}(365)=4.62 ; \mathrm{p}<.01)$. У оквиру конструисаног предикционог модела укупно четири предиктора показала су независан допринос објашњењу отежаног туговања након раскида: статус иницијатора раскида везе, суочавање усмерено на решавање проблема, суочавање избегавањем и анксиозност. Касније је тестирањем доприноса предиктора и варијабле ста- 
тус иницијатора добијена као статистички значајна интеракција са анксиозношћу. Испитаници који имају ниску анксиозност не доживљавају висок ниво дистреса након раскида и међусобно се не разликују у томе у зависности од тога да ли су иницијатори раскида везе били они или њихов партнер. Испитаници који имају високу анксиозност се значајно разликују од испитаника ниских на анксиозности, јер проживљавају упадљиво виши ниво емоционалног дистреса након раскида, али има разлике и у том нивоу у зависности од тога ко је иницијатор раскида. Уколико је партнер иницирао раскид, ниво доживљеног дистреса ठиће значајно виши. Чини се да раскид као сресор може бити окидач интензивне емоционалне реакције код особа са негативним радним моделом себе, с обзиром на то да су такве особе осетљиве на одбацивање од стране других. Овај вид искуства активира систем афективне везаности, што појачава интензитет емоционалног реаговања. Овим истраживањем добили смо да нам боље разумевање разлике у дистресу у зависности од афективне везаности пружају радни модел себе и радни модел других, тј. контекст индивидуалних разлика теорије афективне везаности. Очигледно да су варијабле из домена индивидуалних разлика значајне за боље разумевање ове везе, па би, стога, укључивање и других варијабли из оквира личности и слике о себи могле да донесу значајне увиде.

КљУчнЕ РЕчи: туговање након раскида; романтичне везе; иницијатор раскида; стратегије суочавања; афективна везаност.

Овај чланак је објављен и дистрибуира се под лиценцом Creative Commons Ауторство-Некомерцијално Међународна 4.0 (СС BY-NC 4.0 |

https://creativecommons.org/licenses/by-nc/4.0/).

This paper is published and distributed under the terms and conditions of the Creative Commons Attribution-NonCommercial International 4.0 licence (CC BY-NC 4.0 | https://creativecommons.org/licenses/by-nc/4.0/). 